\title{
NON-FINANCIAL DATA REPORTING BY PUBLIC INTEREST ORGANIZATIONS
}

\author{
Krystyna BARCZYK \\ WSB University in Poznan Faculty in Chorzów; krystyna.barczyk@wsb.chorzow.pl, \\ ORCID: 0000-0001-6385-4781
}

Purpose: The article is an attempt to look at the current state of non-financial information reporting of selected listed companies in order to indicate the area of disclosures and their mutual relationships.

Design/methodology/approach: Research methods used in the article are based on the analysis of applicable legal acts, application of the comparison and inference methods.

Findings: The non - financial data statement as a new element of financial statements is an innovative approach to data reporting for many entities. It is a confirmation of the changes brought by competition, the need to maintain and care for the position on the market. The lack of uniform reporting rules makes it difficult to analyse them.

Originality/value: The statement/report on non-financial information will maybe build its value based on the use of recognized GRI standards. Perhaps their content will better understand the financial statements' stakeholders of the relationship between the financial data.

Keywords: reporting, non-financial information, corporate social responsibility.

Category of the paper: Research paper.

\section{Introduction}

By the end of 2016, reporting of non-financial data by various entities was a voluntary initiative presenting mainly data on sustainable development and Corporate Social Responsibility (CSR). Data in this respect so far show that the number of organizations deciding to publish non-financial data has been growing year on year. Between 2005-2016, 317 reports were published by 110 organizations (www.rejestrraportow.pl) It can therefore be assumed that individuals have recognized non-financial reporting as an instrument for developing and strengthening communication with external stakeholders. 
Amendments to the legal regulations concerning the adjustment of the Polish balance sheet law to the requirements of Directive 2014/95/EU of the European Parliament and of the Council of 22 October 2014 amending Directive 2013/34/EU of the European Parliament and of the Council as regards the disclosure of non-financial information and information on diversity by certain large entities and groups (Official Journal EU, 2014), take into consideration the requirement to recognize and present non-financial information. The amendment to the Accounting Act introduced an annual reporting obligation with respect to public interest entities. The aim of the article is to look at the scope of non-financial reporting of selected listed companies and to try to answer the questions: do the legal regulations introduced by the amendment to the Accounting Act supplement CSR reports, are they supposed to be an extension of them or are they an innovative view on reporting non-financial data? Research methods used in the article are based on the analysis of applicable legal acts, application of the comparison and inference methods.

\section{GRI non-financial data reporting standards}

There are many organizations supporting development, evolution and unification of nonfinancial data reporting rules. The most popular are the Global Reporting Initiative (GRI) reporting guidelines. GRI is the most important organization in the area of developing corporate social responsibility standards. It is an independent international not-for-profit organization based in the Netherlands, which works for sustainable development reporting. GRI's history dates back to the 1990s and its original goal was to create a mechanism for environmental responsibility (Czaja-Cieszyńska, 2018). Today, GRI's aim is to create a generally accepted framework for reporting on the economic, environmental and social aspects of an organization's operations; a framework to increase global comparability and quality, providing a balanced and reasonable representation of an organization's positive and negative actions towards sustainable development.(GRI 101) The guidelines within the standards are universal and can be used by organizations operating in business, public administration, or social organizations. GRI reports present social responsibility in connection with the organization's vision, strategy, profile and management system. The first edition of the guidelines was developed in 2000 (the so-called GRI Guidelines). The latest generation of the 2016 GRI Guidelines, the so-called GRI Standards, has been in force since 1 July 2018 and consists of 36 standards, including 3 universal standards and 33 detailed standards which structure is presented in the table below. 
Table 1.

Structure of GRI standards in 2016

\begin{tabular}{|c|l|}
\hline Structure of standards & \multicolumn{1}{c|}{ Scope } \\
\hline \multirow{2}{*}{ UNIVERSAL STANDARDS } & GRI 101 Standard: Basic information \\
\cline { 2 - 2 } & GRI 102 Standard: Profiled indicators \\
\cline { 2 - 2 } & GRI 103 Standard: Management approach \\
\hline \multirow{2}{*}{ THEMATIC STANDARDS } & Economic standards (GRI 200) \\
\cline { 2 - 2 } & Environmental standards (GRI 300) \\
\cline { 2 - 2 } & Social standards (GRI 400) \\
\hline
\end{tabular}

Source: www.globalreporting.org/standards/gri-standards-download-center.

When preparing CSR reports, any number of standards can be used - either in whole or in selected parts only, which gives more freedom and flexibility in disclosing non-financial data. The scope of information covered by the thematic (detailed) standards is very extensive and allows for the presentation of information relating to three areas. The list of detailed standards together with the scope of possible disclosures is presented in Table 2. The scope of the subject matter includes environmental, social and economic issues.

Table 2.

List of indicators of thematic standards

\begin{tabular}{|c|c|c|c|}
\hline Group of indicators & $\begin{array}{c}\text { Number } \\
\text { of } \\
\text { indicators }\end{array}$ & Subject of measurement & $\begin{array}{c}\text { Scope of possible } \\
\text { detailed } \\
\text { disclosures }\end{array}$ \\
\hline \multirow[t]{6}{*}{ Economic indicators GRI 200} & 6 & $201-$ Economic results & 4 \\
\hline & & 202 - Presence on the market & 2 \\
\hline & & 203 - Indirect economic impact & 2 \\
\hline & & 204 - Purchasing practices & 1 \\
\hline & & 205 - Anti-corruption actions & 3 \\
\hline & & 206 - Anti-corruption measures & 1 \\
\hline \multirow[t]{8}{*}{$\begin{array}{l}\text { Environmental indicators } \\
\text { GRI } 300 \\
\end{array}$} & 8 & 301 - Materials/Raw materials & 3 \\
\hline & & 302 - Energy & 5 \\
\hline & & 303 - Water and wastewater & 5 \\
\hline & & 304 - Biodiversity & 4 \\
\hline & & $305-$ Emissions & 7 \\
\hline & & 306 - Wastewater and waste & 5 \\
\hline & & $\begin{array}{l}307 \text { - Compliance with environmental } \\
\text { regulations }\end{array}$ & 1 \\
\hline & & $\begin{array}{l}308 \text { - Assessment of the supplier's } \\
\text { environment }\end{array}$ & 2 \\
\hline \multirow[t]{11}{*}{ Social indicators GRI 400} & 19 & 401 - Employment & 3 \\
\hline & & $\begin{array}{l}402 \text { - Relations between employees and } \\
\text { the management }\end{array}$ & 1 \\
\hline & & 403 - Occupational health and safety & 10 \\
\hline & & 404 - Training and education & 3 \\
\hline & & 405 - Diversity and equal opportunities & 2 \\
\hline & & 406 - Non-discrimination & 1 \\
\hline & & $\begin{array}{l}407 \text { - Freedom of association and } \\
\text { collective bargaining }\end{array}$ & 1 \\
\hline & & 408 - Child labour & 1 \\
\hline & & 409 - Forced or compulsory labour 1 & \\
\hline & & 410 - Security practices & 1 \\
\hline & & 411 - Indigenous peoples rights & 1 \\
\hline
\end{tabular}


Cont. table 2.

\begin{tabular}{|l|l|l|c|}
\hline & & $\begin{array}{l}412 \text { - Assessment in terms of human } \\
\text { rights }\end{array}$ & 3 \\
\hline & & 414 - Local communities & 2 \\
\hline & & $\begin{array}{l}414 \text { - Supplier's assessment from a social } \\
\text { perspective }\end{array}$ & 2 \\
\hline & $\begin{array}{l}415 \text { - Rules for participation in public } \\
\text { life }\end{array}$ & 1 \\
\hline & 416 - Customer health and safety & 2 \\
\hline & & 417 - Labelling of products and services & 3 \\
\hline & & 418 - Customer privacy & 1 \\
\hline & & 419 - Compliance with regulations & 1 \\
\hline
\end{tabular}

Source: www.globalreporting.org/standards/gri-standards-download-center.

The new modular format of GRI standards allowed for further changes resulting from the dynamic development in sustainability reporting (Sikacz, 2018) to compare and analyse the information presented.

\section{Review of selected areas of non-financial reports prepared according to GRI Standards}

In order to compare and assess the scope of the information presented in the sustainability reports in accordance with the requirements of the CRS reports, four listed companies were selected which prepare reports with non-financial data according to the new GRI Standards. The analysis covered the reports of selected listed companies from various industries for which social activity is not a statutory activity. The selected entities have at least several years of experience in presenting and sharing non-financial data.

The table below presents the range of indicators used in the area of universal standards (100) and disclosures in the area of thematic standards $(200,300,400)$ in tables 3 and 4.

The broad disclosures in CRS reports should bring tangible benefits to the publishing entity, such as an image, the value of which cannot be determined. The entity's image and its reputation contribute to the stability of the entity, positive perception by the outside world, minimize business risk and contribute to the creation of greater goodwill (Emerling, 2018).

Table 3.

Scope of CSR reporting of selected listed companies for 2018 in terms of detailed standards

\begin{tabular}{|c|c|c|c|c|}
\hline $\begin{array}{c}\text { Organisation name } \\
\text { Number of GRI } \\
\text { indicators }\end{array}$ & Industry & $\begin{array}{c}\text { Economic } \\
\text { standards }\end{array}$ & $\begin{array}{c}\text { Environmental } \\
\text { standards }\end{array}$ & Social standards \\
\hline ENEA SA Group & power sector & $203-1$ & $301-1$ & $401-(1-2)$ \\
\hline $\mathbf{1 2}$ & & & $302-1$, & $403-2$ \\
\hline & & & $303-3$, & $404-2$ \\
\hline & & & $304-1$ & $412-2$ \\
\hline & & & $305-1,305-7$, & \\
\hline & & & $307-1$, & \\
\hline & & & $306-2$ & \\
\hline
\end{tabular}


Cont. table 3.

\begin{tabular}{|c|c|c|c|c|}
\hline Energa Group & power sector & $\mathbf{2 0 1 - 2}$ & $\mathbf{3 0 4 - ( 1 - 2 )}$ & $\mathbf{4 0 1 - ( 1 - 2 )}$ \\
\hline $\mathbf{1 3}$ & & $203-(1-2)$ & $305-5,305-7$ & $403-(1-2)$ \\
\hline & & $\mathbf{2 0 4 - 1}$ & & $\mathbf{4 0 4 - 2}$ \\
\hline & & & & $405-1$ \\
\hline & & & & $412-2$ \\
\hline & & & & $413-1$ \\
\hline & & & & $417-(2-3)$ \\
\hline KGHM SA & $\begin{array}{c}\text { mining and } \\
\text { metallurgy }\end{array}$ & $201-1$ & $301-1$ & $401-(1-2)$ \\
\hline $\mathbf{1 1}$ & & $203-(1-2)$ & $302-1$ & $403-(2-4)$ \\
\hline & & & $304-4$ & $404-(1-2)$ \\
\hline & & & $305-1$ & $405-1$ \\
\hline & & & $306-(1-2)$ & \\
\hline & & & & $307-1$ \\
\hline Orlen SA Group & fuel and energy & $201-1$ & $301-1$ & $401(1-2)$ \\
\hline & & $203-(1-2)$ & $302-1,302-4$ & $403-(2-4)$ \\
\hline & & $204-1$ & $303-1,303-4$ & $404-(1-2)$ \\
\hline & & $205-1$ & $305-1,305-7$ & $405-1$ \\
\hline & & & $306-(1-2), 306-4$ & $414-1$ \\
\hline & & & $307-1$ & $416-(1-2)$ \\
\hline & & & $308-1$ & $417-1$ \\
\hline & & & & $418-1$ \\
\hline & & & & $419-1$ \\
\hline
\end{tabular}

Source: https://www.enea.pl/pl/grupaenea/odpowiedzialny-biznes/raportowanie-csr, https://www.orlen.pl/PL/Odpowiedzialny_Biznes/Archiwum/RaportyCSR/Strony/default.aspx $\mathrm{https} / / / \mathrm{com} / \mathrm{pl} /$ zrownowazony-rozkghm.woj/raporty-izasoby, https://grupa.energa.pl/otoczenie/raporty-csr.

Table 4.

Scope of CSR reporting of selected listed companies for 2018 in the universal scope

\begin{tabular}{|c|l|l|l|}
\hline $\begin{array}{c}\text { Organisation name } \\
\text { Number of GRI } \\
\text { indicators }\end{array}$ & Industry & Profiled indicators & $\begin{array}{c}\text { Management } \\
\text { approach }\end{array}$ \\
\hline ENEA Group & power sector & $102-(1-16)$ & $103-(1-3)$ \\
\hline $\mathbf{3 8}$ & & $102-18$ & \\
\hline & & $102-(40-49)$, & $103-(1-3)$ \\
\hline Energa Group & power sector & $102-(50-56)$ & \\
\hline $\mathbf{1 5}$ & & $102-(6-7)$, & \\
\hline & & $102-10$ & \\
\hline & & $102-(15-17)$ & \\
\hline & & $102-40$ & \\
\hline & & $102-42$ & $103-(1-3)$ \\
\hline & & $102-(46-47)$ & \\
\hline & & $102-53$ & \\
\hline & & $102-55$ & \\
\hline & & $102-(1-18)$ & \\
\hline & & $102-22$ & \\
\hline & & $102-35$ & $102-40$ \\
\hline
\end{tabular}

Source: https://www.enea.pl/pl/grupaenea/odpowiedzialny-biznes/raportowanie-csr,

https://www.orlen.pl/PL/Odpowiedzialny_Biznes/Archiwum/RaportyCSR/Strony/default.aspx,https:// com/pl/zrownowazony-rozkghm.woj/raporty-i-zasoby, https:/grupa.energa.pl/otoczenie/raporty-csr. 
Reporting only on the results and financial situation is not a sufficient condition for a modern company to gain a competitive advantage. To survive, an enterprise must be important for the community. From the information included in the non-financial reports of selected companies, we can see a significant range of information presented and GRI indicators used. In the group of economic indicators we will find issues such as: economic performance, purchasing practices, indirect economic impact. The environmental responsibility includes, among others, issues related to the acquisition of materials, water and sewage management, as well as compliance of contracted activities with environmental regulations. Responsibility in the social dimension includes, among others: issues concerning employment, development opportunities, additional benefits as well as support for social initiatives. It is worth noting that the data have a comparable structure, which allows for their easy evaluation in the analysed areas. Taking into account the universal nature of reports according to GRI Standards, it is worth considering the introduction of an obligation to report non-financial data for all public interest organizations according to the above-mentioned standards. The universality of the standards is confirmed by the fact that worldwide 13,958 organizations have published 55,793 reports, 33,197 of which were prepared in accordance with GRI standards.

\section{Non-financial data as a mandatory part of annual reporting}

Non-financial reporting is a natural consequence of the growing importance of the idea of sustainable development and the concept of Corporate Social Responsibility that was created on its foundations. In recent years, the disclosure of non-financial information has also become a trend in other sectors of the economy, e.g. among small and medium-sized enterprises or nongovernmental organizations (Czaja-Cieszyńska, 2018). Since the traditional reporting model was created, there have been huge transformations in the way companies conduct business activity and create value (Krasodomska, 2012). These are changes which financial accounting seems to be unable to keep up with. The obligation to report non-financial data for a specific group of business entities was introduced by an amendment to the Accounting Act, effective from 01.01.2017 (Kościelniak, 2014). The amendment defined the basic conditions for the nonfinancial data statement/report for entities subject to the balance sheet law. The scope of entities covered by the amendment, and thus the new reporting obligations, includes public interest entities operating in the financial market on the basis of banking law, insurance and reinsurance regulations or regulations on cooperative savings and credit unions, issuers of securities on a regulated market or in an alternative trading system, payment institutions, electronic money institutions, investment and pension funds and entities intending to carry out such activities defined as public interest entities (PIEs). An EU directive (like the Accounting Act) has identified the source guidelines that should be used for the report 'as a national or EU framework' such as the UN Global Compact, the UN Guiding Principles on Business and 
Human Rights implementing the UN framework, the OECD Guidelines for Multinational Enterprises, the ISO 26000 standard, the ILO Tripartite Declaration of Principles or the Global Reporting Initiative - GRI or other internationally recognised framework.

The scope of information in the statement/report shall include the necessary information relevant to an understanding of the development, performance and impact of the entity's operations on environmental, social and employee-related areas (ESGs, key risk areas and nonfinancial performance indicators. Detailed arrangements in this regard are set out in Articles $49 \mathrm{~b}$ and 55 of the Accounting Act (Fig. 1).

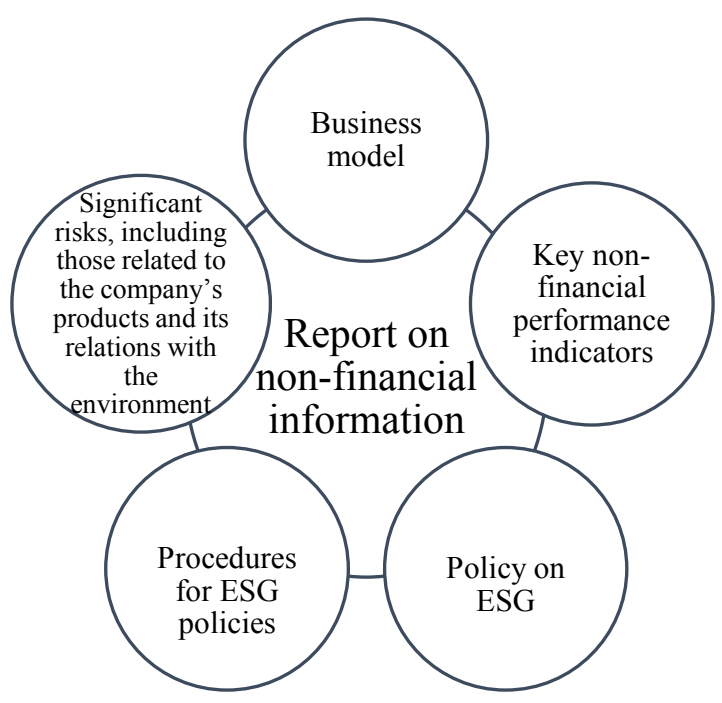

Figure 1. The scope of information in the non-financial statement according to the Accounting Act. Source: Accounting Act, Art. 49 b sec. 2 Journal of Laws of 2019, item 351 of 22.02.2019, Art. 49b.

The obligation to prepare statements/reports on non-financial information shall cover about 300 entities in Poland. More than half are listed companies.

The obligation to report non-financial data has been imposed on entities that meet certain criteria in relation to the legal form, the number of employees, net revenues generated from the sale of goods and products and the value of the balance sheet total (Fig. 2).

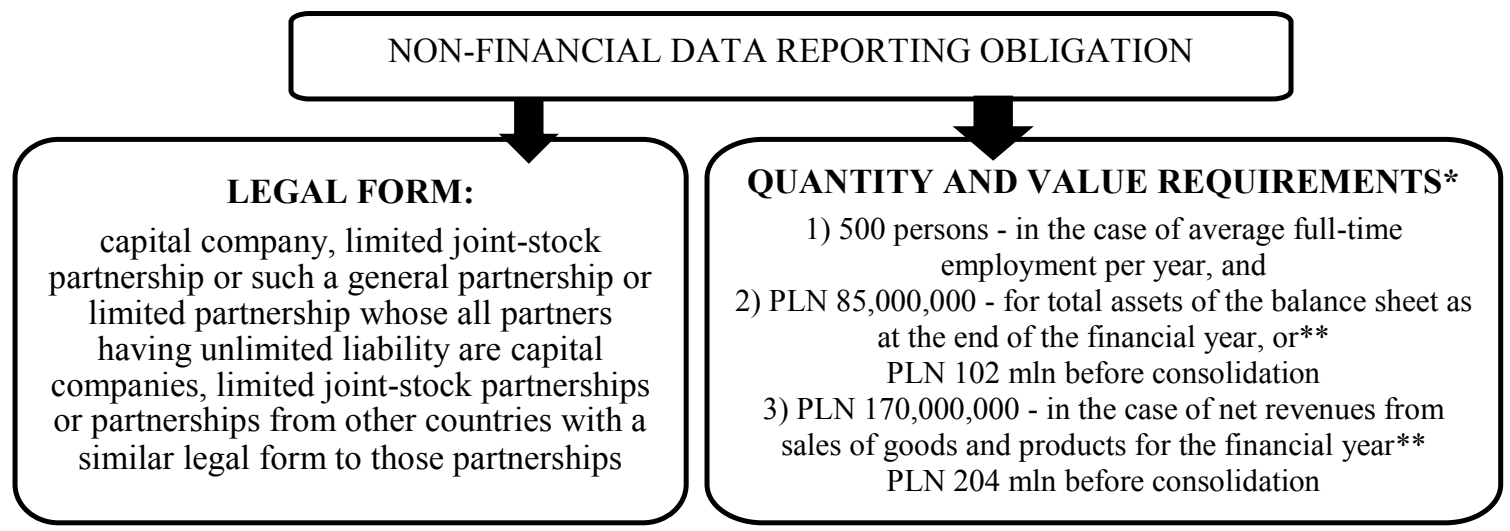

* in the financial year for which it draws up its financial statements and in the year preceding that year at the level of individual financial statements

** either individually or after consolidation

Figure 2. Obligation to report non-financial data according to the Accounting Act. Source: Accounting Act of 29.09. 1994, Journal of Laws of 2019, item 351 of 22.02.2019, Art. 49b point 1 
The Act gives the entity the right to choose the reporting standards. Entities may apply any standards or guidelines, whether national, EU, international or their own rules. When using the outlined standards it should disclose which guidelines/standards have been used. Most entities preparing CRS reports according to GRI standards also use them to present non-financial information as required by the Accounting Act. An example is the data disclosed by Enea Group on the indicators used in the preparation of non-financial information in accordance with the Accounting Act (Table 4).

Table 4.

The scope of information and list of indicators included in the Enea Group's non-financial information in 2018

\begin{tabular}{|c|c|c|c|}
\hline $\begin{array}{l}\text { The scope of the information in the non- } \\
\text { financial information statement }\end{array}$ & $\begin{array}{l}\text { List of indicators } \\
\text { used in the } \\
\text { statement }\end{array}$ & $\begin{array}{l}\text { Information in } \\
\text { the CRS / GRI } \\
\text { indicators }\end{array}$ & $\begin{array}{l}\text { Link to information } \\
\text { in the CRS }\end{array}$ \\
\hline $\begin{array}{l}\text { 1. Methodology for the preparation of } \\
\text { the Non-Financial Information } \\
\text { Statement }\end{array}$ & GRI Standards & 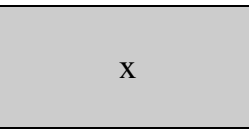 & $\mathrm{x}$ \\
\hline 2. $\quad$ Business model description & GRI 102-2 & $\begin{array}{c}\text { Business model/ } \\
\text { GRI 102-1-2 }\end{array}$ & Yes \\
\hline $\begin{array}{l}\text { 3. Information on expected events and } \\
\text { issues being the subject of ongoing } \\
\text { negotiation }\end{array}$ & None & none & $\mathrm{x}$ \\
\hline $\begin{array}{l}\text { 4. Key non-financial performance } \\
\text { indicators }\end{array}$ & None & GRI- 103-(1-3) & $\begin{array}{l}\text { Yes / Key } \\
\text { performance } \\
\text { indicators }\end{array}$ \\
\hline $\begin{array}{l}\text { 5. Non-financial risks related to the } \\
\text { operations of the ENEA Capital } \\
\text { Group }\end{array}$ & Accounting Act & GRI 103-2 & $\begin{array}{c}\text { Yes/ } \\
\text { Map of non-financial } \\
\text { risks }\end{array}$ \\
\hline $\begin{array}{l}\text { 6. Environmental issues, description of } \\
\text { due diligence policies and } \\
\text { procedures and their results }\end{array}$ & None & $\begin{array}{l}\text { GRI 103-1-3, } \\
\text { GRI 102-11, } \\
\text { GRI 307-1 } \\
305-, 305-7 \\
301-1,302-1\end{array}$ & $\begin{array}{c}\text { Yes/ Approach to } \\
\text { environmental } \\
\text { management } \\
\text { Emissions } \\
\text { Materials and raw } \\
\text { materials } \\
\text { Water }\end{array}$ \\
\hline $\begin{array}{l}\text { 7. Employee issues, description of due } \\
\text { diligence policies and procedures } \\
\text { and their results }\end{array}$ & $\begin{array}{l}\text { Accounting Act } \\
\text { GRI 102-8, } \\
\text { 401-1, 403-2 }\end{array}$ & $\begin{array}{c}102-16 \\
103-1-3,102-8 \\
404-2,403-2 \\
303-3\end{array}$ & $\begin{array}{c}\text { Work of employees, } \\
\text { Employment policy } \\
\text { Employee potential } \\
\text { management } \\
\text { Development } \\
\text { initiatives } \\
\text { Work comfort and } \\
\text { safety } \\
\end{array}$ \\
\hline $\begin{array}{l}\text { 8. Social issues, description of due } \\
\text { diligence policies and procedures } \\
\text { and their results }\end{array}$ & Accounting Act & GRI 102-13 & $\begin{array}{l}\text { Involvement in social } \\
\text { initiatives }\end{array}$ \\
\hline $\begin{array}{l}\text { 9. Human rights issues, description of } \\
\text { due diligence policies and } \\
\text { procedures and their results }\end{array}$ & Accounting Act & none & none \\
\hline $\begin{array}{l}\text { 10. Anti-corruption and anti-bribery } \\
\text { issues, description of due diligence } \\
\text { policies and procedures and their } \\
\text { results }\end{array}$ & $\begin{array}{l}\text { Accounting Act } \\
\text { GRI 205-2 }\end{array}$ & $\begin{array}{l}\text { GRI } 103-1-3, \\
\quad 412-2\end{array}$ & Compliance \\
\hline
\end{tabular}

Source: Report of the Management Board on the activities of ENEA SA and Enea Capital Group in 2018, report 2018.crs.enea.pl. 
Summarizing and evaluating the methodology adopted by the Enea Group to prepare a statement on non-financial information in accordance with the requirements of the Accounting Act, it can be stated that, as expected, the entity focused on GRI standards having many years of experience in this area by publishing CRS reports by 2011. However, when analysing the information included in the non-financial information statement, it is only partially covered by GRI standards, only 3 areas out of 10 presented. By contrast, when comparing disclosures in the CRS report and the non-financial data statement, 7 out of 10 areas presented in the statement were identified as being directly relevant to the disclosure. The conclusion is that the information in the non-financial statement/data report is only to a limited extent a mapping of CRS reporting data, despite the indication of more areas where this would be possible. The similarity of the issues presented in the statement/report to CRS reports is clearly an advantage. Like early stage CRS reports, the statement/report as a new element of the financial statements is an innovative approach to data reporting for many entities. It is a confirmation of the changes brought about by competition, the need to maintain and care of a position in the market. It gives an opportunity to build new relations with the environment and to take care of one's image, which often translates into financial results. In the following years it will be possible to assess if this goal was achieved by assessment by the stakeholders of the usefulness and quality of the issues presented in the statement/report.

\section{Summary}

Financial reporting is widely accepted because of many factors such as standards, valuation and data presentation rules, control and audit. Reporting in the area of non-financial data as a new element of reporting in the Polish balance sheet law is a challenge for many organizations that have not attempted to present and disclose data in social responsibility reports so far. As research has shown, many entities have experience in CRS reports, thanks to which they build relations with the environment taking care of their image and market position. The non-financial information statement/report will build its value perhaps using recognized GRI standards. Perhaps their content will allow the stakeholders of financial statements to better understand the relationship between financial data subject to their evaluation and the organization's non-business activities. 


\section{References}

1. Czaja-Cieszyńska, H. (2018). Standardy GRI - kierunek dla raportowania na rzecz zrównoważonego rozwoju $\mathrm{w}$ organizacjach pozarządowych w Polsce. Kolegium Zarządzania i Finansów, 164, 49-61.

2. Dyrektywa Parlamentu Europejskiego i Rady 2014/95/UE z dnia 22 października 2014 r. zmieniającej dyrektywę Parlamentu Europejskiego i Rady 2013/34/UE w odniesieniu do ujawniania informacji niefinansowych i informacji dotyczących różnorodności przez niektóre duże jednostki oraz grup Dz. Urz. UE L 330 z 15.11.2014, str. 1, z późn. zm., 2014/95/UE.

3. Emerling, I. (2018). Znaczenie ujawnień niefinansowych dla inwestorów i wizerunku jednostki gospodarczej. Studia Ekonomiczne, Zeszyty Naukowe Uniwersytetu Ekonomicznego w Katowicach, 369, 40-53.

4. GRI 101: Foundation, Consolidated Set of GRI Sustainability Reporting Standards, GRI 2016, p. 3, https:// www.globalreporting.org.

5. https://database.globalreporting.org/.

6. https://seg.org.pl/sites/seg13.message-asp.com/files/seg_esg-20.

7. Kościelniak, H. (2014). Raportowanie odpowiedzialnego biznesu w przedsiębiorstwach transportowych. Logistyka, 6, 5725-5731.

8. Krasodomska, J. (2012) Zintegrowana sprawozdawczość spółek w 2020 roku. Zeszyty Teoretyczne Rachunkowości, 66(122), SKwP, 101-110.

9. seg.org.pl/pl/projekty/analiza-esg-spolek-w-polsce-edycja-1.

10. Sikacz, H. (2018) Wskaźniki ekonomiczne w raportach zintegrowanych wybranych grup kapitałowych- wyniki badań. Studia Oeconomica Posnaniensia, 6, 2, pp. 35-53.

11. Ustawa z dnia 29.09. 1994 r. o rachunkowości, Dz. U. z 2019 r. poz. 351 z dnia 22.02.2019.

12. www.globalreporting.org/standards/gri-standards-download-center.

13. www.rejestrraportow.pl. 